\title{
Ribosomally synthesized peptides from natural sources
}

\author{
Nidhi Singh and Jayanthi Abraham \\ There are many antibiotic-resistant microbial pathogens that have emerged in recent years causing normal infections to become \\ harder and sometimes impossible to treat. The major mechanisms of acquired resistance are the ability of the microorganisms \\ to destroy or modify the drug, alter the drug target, reduce uptake or increase efflux of the drug and replace the metabolic step \\ targeted by the drug. However, in recent years, resistant strains have been reported from almost every environment. New \\ antimicrobial compounds are of major importance because of the growing problem of bacterial resistance, and antimicrobial \\ peptides have been gaining a lot of interest. Their mechanism of action, however, is often obscure. Antimicrobial peptides are \\ widespread and have a major role in innate immunity. An increasing number of peptides capable of inhibiting microbial growth \\ are being reviewed here. In this article, we consider the possible use of antimicrobial peptides against pathogens.
}

The Journal of Antibiotics (2014) 67, 277-289; doi:10.1038/ja.2013.138; published online 12 February 2014

Keywords: antibiotics; antimicrobial agents; bacteriocins; multidrug-resistant strains

\section{INTRODUCTION}

Antibiotics have significantly improved our quality of health; however, the overuse of antibiotics has led to the emergence of multidrugresistant microorganisms, and the subsequent constant demand for the discovery of novel antibiotics. To this end, antimicrobial peptides have attracted much attention as a novel class of antibiotics. Antimicrobial peptides are gene-encoded, ribosomally synthesized polypeptides. The natural antimicrobial peptides have been isolated from practically all living organisms, ranging from prokaryotes to humans. They have a key role in innate immunity of eukaryotes and are produced by many organisms including bacteria, fungi, insects, plants and higher animals. In mammals, antimicrobial peptides are generated by epithelial cells in the respiratory tract, gastrointestinal tract etc., the same is done by mucous cells in the mucous gland. ${ }^{1}$ So far, over 800 antimicrobial peptides have been isolated and described. They have great ancient evolutionary importance preserved in mammals. They can protect against a broad array of infectious agents, such as bacteria, fungi, parasites and viruses, and show cytotoxicity against cancer cells. They are usually small peptides (30-60 a.a). They are commonly strongly cationic and heat stable $\left(100{ }^{\circ} \mathrm{C}\right.$ for $\left.5 \mathrm{~min}\right)$. Their significant advantage resides in the global mechanism of their action, which is remarkably different from that of conventional antibiotics. Usage of these peptides will gain widespread increase, as more and more bacteria may develop the ability to resist conventional antibiotics owing to the abuse of these drugs worldwide. ${ }^{2}$

Ribosomally synthesized peptides as new antimicrobials Antimicrobial peptides are ribosomally synthesized antibiotic peptides produced by nearly all organisms, from bacteria to plants and animals. Structures of antimicrobial peptides encompass molecules ranging in size from 6 to 60 amino-acid residues, being linear ( $\alpha$-helical and non-helical), cyclic (Rhesus $\beta$-defensins, Rhesus $\theta$-defensins) or crosslinked by one, two, three or more internal disulfide bridges. Antimicrobial peptides consisting of three disulfide bonds include insect defensins and mammalian $\alpha$ and $\beta$ defensins. In terms of amino-acid composition and net surface charge, they may be rich in one type of amino-acid residue. Certain ribosomally synthesized antibiotic peptides show an exceptionally broad spectrum of activity against Gram-negative and -positive bacteria, fungi as well as viruses and parasites. Therefore, They or their derivatives may represent potentially new classes of antimicrobial drugs. At present, a few of them are in commercial development and some have advanced into clinical trials. ${ }^{3-5}$

There are several indications that new approaches are required to combat emerging infections. One is the pattern in the death rate from infection, for example, from 1900 to 1980, the rate dropped from 797 to 36 per 100000 people. $^{6}$ However, owing to HIV and spread of drug-resistant bacteria, the death rate became double from 1980 to 2000. A second indication of the need for novel antibacterial therapeutics is the almost 40-year innovation gap between introductions of new molecular classes of antibiotics. ${ }^{7}$ Third is the recent trend followed by pharmaceutical companies to leave the antibacterial and antifungal fields, suggesting a future decrease of developing new antibacterial drugs. ${ }^{8,9}$

\section{Importance of peptides}

Many infectious diseases have been known for thousands of years, but over the past few years the number of infections (new) has increased. Some examples include the Lyme disease caused by Borrelia 
burgdorferi, Legionnaires' disease caused by Legionella pneumophila, peptic ulcers caused by Helicobacter pylori, antibiotic-associated diarrhea caused by Clostridium difficile and AIDS caused by human immunodeficiency virus. In addition, microorganisms are constantly evolving, finding new places to live and new ways to survive, and adapting to new situations. In this process, microorganisms may shift their host or become pathogenic from non-pathogenic. Thus, it is important to continue to find anti-infective agents that can be used to treat these infections. Development of novel classes of drugs, drugs with fewer side effects and drugs with shorter lengths of treatment are key in continuing the fight against infectious disease.

\section{Understanding the biological process to devise new novel antibiotics}

The aims of new criteria for successful anti-infective chemotherapeutics should be to preserve the efficiency of each anti-infective agent as long as possible by delaying the emergence of drug resistance and to spare the normal microbiota as much as possible. The normal microbiota are thought to be invaluable allies to prevent pathogenesis and protect their niches from new competitors, allow the sustainability of the species diversity that impedes virulence ${ }^{10}$ and by helping to preserve the integrity and function of the epithelia and the immune system. ${ }^{11,12}$

Anyhow, killing all pathogens with an extrinsic antimicrobial agent may not be necessary or even desirable. For example, the eponymous gold pigment of Staphylococcus aureus is a carotenoid that protects the bacterium from oxidative injury by host immune cells. Interruption of bacterial pigment synthesis makes the pathogen much easier for host cells to kill but does not impair bacterial growth in vitro. ${ }^{13}$ Thus, just stopping the spread of the pathogen would be sufficient for the host microbiota to prevent the invader.

\section{CLASSIFICATION OF ANTIMICROBIAL PEPTIDES}

Other than microbes there are a wide variety of sources including humans, animals and plants that are being classified in four groups, that is:

1. Cationic peptide enriched with a specific amino acid: these are rich in proline, arginine, tryptophan, phenylalanine and glycine. For example, abaecin, apidaecin from honeybees and indolicidine from cattle (Table 1).

2. Linear cationic $\alpha$-helical peptides: these do not have cystein residues. For example, cecropins, andropin, moricin and mellitin from insects (Table 1).

3. Anionic peptide: these are rich in glutamic acid and aspartic acid. For example, maximin $\mathrm{H} 5$ from amphibian and dermcidin from humans (Table 2).

4. Anionic and cationic peptised having cystein: contain the 1-3 disulfide bond. For example, brevinins, protegrin and defensins (Tables 1 and 2).

Apart from already mentioned peptides, there are neutral antimicrobial peptides that are less active than the cationic peptides and the anionic peptide complexed with zinc (Table 3). The amino-acid sequences are mentioned in Table 4.

\section{PROPERTIES OF RIBOSOMALLY SYNTHESIZED ANTIMICROBIAL PEPTIDES}

Transmembrane potential

A first step in the mechanism of action is the electrostatic interaction between the cationic peptide and the negatively charged components of the membrane of the pathogen. A fundamental difference between microbial and mammalian cells can be found in the charge separation between the extracellular and intracellular aspects of the cytoplasmic membrane. This electrochemical gradient, resulting from differing extents and rates of proton flux across the membrane, is termed the transmembrane potential $(\Delta \psi)$. The difference in $\Delta \psi$ between certain microorganisms and host cells may provide a means of selective targeting of microorganisms by cationic antimicrobial peptides. For example, normal mammalian cells exhibit a $\Delta \psi$ ranging from -90 to $-110 \mathrm{mV}$. However, bacterial pathogens in the logarithmic growth phase commonly exhibit $\Delta \psi$ of -130 to $-150 \mathrm{mV}$. Such significant differences in membrane electrochemistry have been hypothesized as additional parameters guiding selective toxicity of antimicrobial peptides, through a mechanism that has been termed a self-promoted uptake. ${ }^{14}$

The carboxyl-terminal modification of indolicidin increases its antimicrobial activity against both Gram-negative and -positive bacteria presumably by increasing its net positive charge. This was consistent in part with subsequent outer membrane permeabilization by the carboxyl-terminal modification. ${ }^{15}$ On the other hand, many positive charges can lead to a loss of activity. For example, the reduction in the activity of magainin analogs is either due to increased repulsion among peptide monomers or due to strong peptide association with the anionic lipids. The positive charges are also responsible for the specificity of the peptide toward the target membrane, as difference in only one charge can lead to marked differences in properties of pardaxin and indolicidin. ${ }^{16}$

The usually higher, negative-inside, transmembrane potential found in bacteria promotes their interaction while acting as a potential driving force for peptide insertion and translocation.

\section{Signaling capacity}

Antimicrobial peptides can have a possible role in cell signaling also. As human defensins (HNP-1, HNP-2 and NP-3) are potent inhibitors of protein kinase $\mathrm{C}$, they do not have any role in other kinases. ${ }^{17}$ The molecule, first being discovered as the epidermal growth factor receptor kinase inhibitor was also found to have antibacterial properties. ${ }^{18}$ Another fact suggesting a possible role of antimicrobial peptides in the modulation of signaling pathways is the identification of defensins in lymphocyte nuclei. Defensins (HPN1-3) have also been found to be associated with the lymphocyte nuclear fraction, suggesting a cell function and regulation for these peptides. ${ }^{19}$ PR-39 is a proline- and arginine-rich peptide that can bind to the adapter protein p130 (Cas) ${ }^{20}$ involved in various cellular processes including cell adhesion, migration and transformation. ${ }^{21}$ Moreover, it binds a subunit of phosphoinositide 3-kinase and inhibits kinase activity. ${ }^{20}$ These natural antibiotics can also modulate the immune response through paracrine or endocrine pathways.

The cell-to-cell communication involved in these processes is dependent on the usage of small-signal molecules produced and released into the environment by the microorganisms. These communication molecules are referred to as pheromones and act as chemical messengers that transmit information across space. Explanation of the chemical structure of these pheromones reveals that most of them are unmodified peptides, post-translationally modified peptides, $\mathrm{N}$-acyl homoserine lactones or butyrolactones. Lactone-based pheromones are the preferred communication signals in Gram-negative bacteria, ${ }^{22}$ whereas peptide-based pheromones are the predominant extracellular signals among Gram-positive bacteria. $^{23}$ 
Table 1 Other sources of cationic ribosomally synthesized antimicrobial peptides

\begin{tabular}{lll}
\hline Name & Sources & Characteristics \\
\hline Abaecin & Apis mellifera L., honeybee & $\begin{array}{l}\text { 34, Proline rich, highly active against an apidaecin-resistant Xanthomonas strain. } \\
\text { Gram-positive and Gram-negative bacteria. }{ }^{89}\end{array}$ \\
AcAMP & Aspergillus clavatus ES1 & $\begin{array}{l}94,6 \mathrm{kDa} \text { size, cysteine rich, sensitive to proteolytic enzymes, thermostable, antifungal } \\
\text { and antibacterial, biological control of plant diseases. }\end{array}$ \\
Amino acid-enriched & Depending on the organism they are derived from.
\end{tabular}

Proline and glycine

Cystine

Histidine

Antiviral protein $Y 3$

Apidaecin IA

Aurein

Pleurotus citrinopileatus, golden oyster mushroom Apis mellifera L., honeybee

Litoria aurea, Litoria raniformis, frog

Bactenecin

Bactericidin B2

Beta-hairpin

Brevinin

Buforins

Caerin 1.1

Catestatin

Cecropins

Ceratotoxin A

Clavanins

Conolysin-Mt

Cupiennin ID

Defensins

Dermaceptin B2

Discodermin A

Drosocin

ECAMP 1

ECAMP 2

EcLTP

Esculentin 1

Gomesin

Hedistin

Heliomicin

Hepcidin-25

Hinnavin II

Histone-derived

compounds

Hydramacin

Im-1

Indolicidin

KLAL

Lactoferricin B
Bos taurus, cow

Bos taurus, cow bovine neutrophils

Manduca sexta, tobacco hornworm

Both vertebrates and invertebrates

Rana brevipoda porsa from Japan

B. bufo, toad stomach

Litoria splendid, Litoria rothii, green tree frog

Homo sapiens

Hemolymph of insects

Ceratitis capitata, female reproductive accessory glands of medfly

Salmonids, fish

Conus mustelinus, weasel cone

Cupiennius salei, spiders

Molluscs, acari, arachnids, insects, mammals and plants

Phyllomedusa bicolor, south American frog

Discodermia kiiensis, sea sponge

Drosophila, fruit fly

Echinochloa crus-galli, seeds

Echinochloa crus-galli $L$

Echinochloa crus-galli L

Rana esculenta, edible frog

Acanthoscuria gomesiana, spider hemocytes

Nereis diversicolor, Coelomocytes

Heliothis virescens, tobacco budworm

Homo sapiens, liver of humans

Artogeia rapae, larval hemolymph of cabbage butterfly

Toad and fish epithelia

Hydra vulgaris, hydra

Isometrus maculates (scorpion), venom

Bovine neutrophils

-

Lumbricus rubellus, earthworm
97, Antiviral against TMV and antitumor against stomach cancer cells in vitro. ${ }^{90}$

18 , Rich in proline and active against Gram-negative bacteria. ${ }^{91}$

13, Helix, active against HIV virus, fungi, cancer, Gram-positive and Gram-negative bacteria. ${ }^{92}$

12, Bridge formation, S-S bond leads to cyclic dodecapeptide, act more against Gramnegative bacteria than the linearized version acting against Gram-positive bacteria. ${ }^{93}$

37 , Induces synthesis of mRNA within $5 \mathrm{~h}$ of induction, act against Gram-positive, Gram-negative and mammalian cells. ${ }^{94}$

2-8 kDa, contain beta-hairpin crosslinked by disulfide bridges.

24, Active against Gram-positive, Gram-negative, viruses and mammalian cells. ${ }^{95}$

$39,90 \%$ Homology to histone H2A, contains helix-hinge-helix domain, anti-endotoxin and anticancer effect. ${ }^{96,97}$

25 Helix, two well-defined helices from L2-K11 and V17-H24, inhibits HIV infection with little effect on T cells. ${ }^{98}$

21, Highly conserved across species, three single-nucleotide polymorphisms G364S, P370L and R374Q, P370L being most active, upregulated on skin injury and is a part of the cutaneous immune system. Chemotactic, fungicidal and bactericidal in action. $^{99}$

3-4 kDa linear ampipathic peptide, no cystein residue, two distinct helical segments. ${ }^{100}$

29, Heat stable, highly basic, amphiphilic and active against Gram-positive and Gram-negative bacteria. ${ }^{101}$

18, Anion-binding residue, iron-binding residue, cysteine residue for disulfide bonds. 102

23, Hemolytic to human erythrocytes, also called moonwalker peptide. Cytolytic to both prokaryotes and eukaryotes. 103

35. Active against Gram-positive bacteria, Gram-negative bacteria and insects. ${ }^{104}$

$48 \mathrm{kDa}$, highly complex, open ended, cystein rich, three and four disulfide bridges.

33, Helix, may contain D-amino acids, works against Gram-positive, Gram-negative bacteria, fungi and cancer cells. ${ }^{105}$

14, Tetradecapeptide containing D-amino acids, antitumor and toxic. ${ }^{106}$

19 , Proline rich, small size, active against Gram-positive and Gram-negative bacteria. 107

37, Helix, hairpin-like peptides, two $\mathrm{S}=\mathrm{S}$ bonds, active against a variety of fungi. ${ }^{108}$

31, Contains two $\mathrm{S}=\mathrm{S}$ bonds, inhibits Phytophthora infestans and also many protists. ${ }^{109}$

30, Lipid transfer proteins, active against Gram-positive as well as protest along with P.infestans. 109

46 , Helix, residue $1-8$ is an antimicrobial region, inhibits Gram-positive bacteria, Gram-negative bacteria, insects and mammalian cells.

18 , Beta, bound to cell surface, $\mathrm{N}$-terminal residue is a polyglutamate, disulfide bonds, works against Gram-positive bacteria, Gram-negative bacteria, fungi, parasites, cancer cells and mammalian cells. ${ }^{110}$

Contains bromo-tryptophans, activity against MRSA and Vibrio alginolyticus, present in NK cells, C-terminal amidation. ${ }^{111}$

44 , Combine helix and beta structure, three disulfide bridges, peptide expression in tobacco improves resistance to pathogens, inhibits C. albicans and P.pastoris. ${ }^{112}$

25 , Cysteine rich, master regulation of iron metabolism, antifungal activity, hairpin structure with four disulfide bonds.

$38,4.14 \mathrm{kDa}$, synergises with lysozymes, $78.9 \%$ identity with cercopin A, more active against Gram-negative than Gram-positive bacteria. ${ }^{113}$

Structurally similar to cecropins, active against fungi and bacteria.

85 a.a, a disulfide bridge-stabilized $\alpha \beta$ motif, belt of positive residues sandwiched by hydrophobic areas, scaffold of knottin protein fold, active against bacteria with multiresistant-human pathogens. ${ }^{114}$

56 , helix, original thionin mutant was replaced to form this peptide, inhibits Grampositive, Gram-negative and insects. ${ }^{115}$

13, Tryptophan rich, bactericidal, carboxy terminal is amidated, so called tridecapeptide amide. ${ }^{116}$

18 Residues, model compounds for potentially amphipathic $\alpha$-helical peptides, random coil structure, $\beta$-form in appropriate conditions, $\alpha$-to- $\beta$ transition is a key step in Alzheimer's disease initiation and insoluble fibril formation, exhibits both antimicrobial and hemolytic activity. ${ }^{117}$

25, Released by pepsin cleavage of lactoferrin, suppress candida cell growth and activate neutrophils. Inhibits Gram-positive bacteria, Gram-negative bacteria, HIV and cancer cells. ${ }^{118}$

62 , Proline rich, active against a broad spectrum of microorganisms with hemolytic activity. 119 
Table 1 (Continued)

\begin{tabular}{|c|c|c|}
\hline Name & Sources & Characteristics \\
\hline Lycotoxin I & Lycosa carolienensis, wolf spider & $\begin{array}{l}25 \text {, Helix, amphipathic } \alpha \text {-helical, inhibits Gram-positive bacteria, Gram-negative } \\
\text { bacteria and insects. }{ }^{120}\end{array}$ \\
\hline Magainins & Xenopus, frog & $\begin{array}{l}\text { Magainin } 1 \text { and magainin } 2-23 \text { each, amphiphilic, nonhaemolytic peptides, analogs to } \\
\text { hormones in GIT or CNS of mammals, small size, active against bacteria, fungus and } \\
\text { protozoans. }{ }^{121}\end{array}$ \\
\hline Maximin 1 & Bombina maxima, Chinese red belly toad & $\begin{array}{l}\text { 27, Active against } E \text {. coli, } S \text {. aureus and has spermicidal effect, also inhibits } \\
\text { Gram-positive bacteria, Gram-negative bacteria, viruses, fungi, cancer cells and } \\
\text { mammalian cells. } 122\end{array}$ \\
\hline Mellitin & Apis mellifera, A. cerana, honeybee venom & $\begin{array}{l}26 \text {, Helix, forms tertramer at high peptide and salt concentration, } \alpha \text {-helix with a bend } \\
\text { between residues } 11-15 \text {, inhibits HIV by suppressing viral gene expression, also active } \\
\text { against colistin-resistant A.baumannii. }{ }^{123}\end{array}$ \\
\hline Meucin & Mesobuthuseupeus, scorpion venom & $\begin{array}{l}\text { Meucin-13 is } 13 \text { a.a and meucin-18 is } 18 \text { a.a long, similar to peptides of frog skin, } \\
\text { mast cells, etc., } \alpha \text {-helical amphipathic design, cytolytic effect on cells, meucin-18 } \\
\text { being more potent. } 124\end{array}$ \\
\hline Myticin C & Mytilus galloprovincialis, mussel hemocytes & $\begin{array}{l}\text { 40, Four intramolecular disulfide bridges, highly polymorphic mRNA, antiviral and } \\
\text { immunoregulatory, cysteine rich, has allelic variants, active against Gram-positive and } \\
\text { Gram-negative bacteria, antifungal and chemotactic. }{ }^{125}\end{array}$ \\
\hline Novicidin & Bovine cathelicidin SMAP-29, domestic sheep & $\begin{array}{l}18 \text { a.a, derived from previous highly toxic antimicrobial peptide ovispirin, hydrophobic } \\
\text { moment, acts by toroidal pore formation. } .^{126}\end{array}$ \\
\hline Oncorhyncin III & Oncorhynchus mykiss, rainbow trout & $\begin{array}{l}6.7 \mathrm{kDa}, 70 \text { residue, one double methylation, active against bacteria in submicromolar } \\
\text { concentrations, sensitive to } \mathrm{NaCl} .127\end{array}$ \\
\hline Paenibacillin & Paenibacillus polymyxa, Gram-positive bacteria & $\begin{array}{l}\text { 30, Lantibiotic with N-terminal acetyl group, against Gram-positive bacteria including } \\
\text { MRSA, Listeria monocytogenes, and Mycobacterium smegmatis, acts by cytolysis. }{ }^{128}\end{array}$ \\
\hline Parasin I & Parasilurus asotus, skin of cat fish & $\begin{array}{l}19 \text {, Amphipathic, } 11 \% \alpha \text {-helical, } 33 \% \beta \text {-sheet and } 56 \% \text { random coils, active against } \\
\text { Gram-positive, Gram-negative bacteria and fungi. } .29\end{array}$ \\
\hline Pardaxins & Pardachirus marmoratus red sea mosses sole, teleost & $\begin{array}{l}35 \text {, Toxic and cytolytic, hydrophobic, rich in aspartic acid, serine, glycine and } \\
\text { alanine. } 130\end{array}$ \\
\hline Perinerin & Nereis aibuhitensis, clamworm & $\begin{array}{l}51,5.97 \mathrm{kDa} \text {, highly basic and hydrophobic, active against bacteria and fungi, serve as } \\
\text { evaluation marker to study biochemistry of the host. }{ }^{131}\end{array}$ \\
\hline Piscidin & Mast cells of fish & $\begin{array}{l}22, \text { Rich in histidine and phenylalanine, amphipathic } \alpha \text {-helical conformation, hemo- } \\
\text { lytic activity. }{ }^{132}\end{array}$ \\
\hline Ponericin G1 & Pachychondyla goeldii, ants & $\begin{array}{l}\text { 30, Helix, adopt an amphipathic } \alpha \text {-helical structure on cell membrane, inhibits Gram- } \\
\text { positive bacteria, Gram-negative bacteria, fungi and insects. }{ }^{133}\end{array}$ \\
\hline PR-39 & Sus, pig bone marrow & $\begin{array}{l}173,49 \% \text { Proline and } 24 \% \text { arginine, important in innate immunity, can alter } \\
\text { mammalian cell gene expression and behavior. }{ }^{134}\end{array}$ \\
\hline Prolixicin & $\begin{array}{l}\text { Rhodnius prolixus, hemipteran insect (adult fat body and } \\
\text { midgut tissue) }\end{array}$ & $\begin{array}{l}21 \text { a.a, } 11 \mathrm{kDa} \text {, two putative phosphorylation sites and no glycosylation sites, active } \\
\text { against Gram-negative and Gram-positive bacteria. }{ }^{135}\end{array}$ \\
\hline PW2 & Synthetic phage display library & $\begin{array}{l}12 \text {, Non-helix beta, rich in tryptophan and proline, anticoccidial peptide, active against } \\
\text { fungi and parasites. }{ }^{136}\end{array}$ \\
\hline Pyrrhocoricin & Pyrrhocoris apterus, Sap sucking bug & $\begin{array}{l}\text { 20, Inhibits ATPase activity of DnaK, proline rich, active against bacteria, fungi, } \\
\text { parasites, insects and rodents. }{ }^{137}\end{array}$ \\
\hline Ranalexin & Rana catesbeiana, bull frog & $\begin{array}{l}20 \text {, Contains intramolecular disulfide bond forming a heptapeptide ring, resembles } \\
\text { polymyxin in structure, amphipathic in nature. }{ }^{138}\end{array}$ \\
\hline Ranateurin & Rana luteiventris, Rana ptetiosa, north American frog & $\begin{array}{l}28 \text { a.a, contains a disulfide bridge, inhibits HIV at a concentration also toxic to T cells. } \\
\text { Toxic to Gram-positive, Gram-negative bacteria and viruses. }{ }^{139}\end{array}$ \\
\hline Strongylocin 1 & Strongylocentrotus droebachiensis, sea urchin & $\begin{array}{l}83 \text { a.a, } 5.6 \mathrm{kDa} \text {, cysteine rich, three sulfide bridges, active against Gram-positive and } \\
\text { Gram-negative bacteria. } 140\end{array}$ \\
\hline Stylisin 2 & Stylissa caribica, Jamaican sponge & $\begin{array}{l}\text { Proline rich, cycloheptapeptide, active against Pseudomonas aeruginosa, Klebsiella } \\
\text { pneumonia and Candida albicans, anticancer, antimmalarial and anti-HIV. }{ }^{141}\end{array}$ \\
\hline Tachyplesin I & Tachypleus tridentatus, horse crab & $\begin{array}{l}\text { 17, } \beta \text {-hairpin conformation stabilized by two disulfide bonds, active against } \\
\text { Gram-positive and Gram-negative bacteria. }{ }^{142}\end{array}$ \\
\hline Temporin & Rana temporaria, European common frog & $\begin{array}{l}\text { 13, C-terminal amidation, hydrophobic residues at posit ion } 1,5 \text { and } 12 . \text { Active against } \\
\text { Gram-positive, Gram-negative bacteria, viruses and parasites, chemotactic. }{ }^{143}\end{array}$ \\
\hline Thionin & Plants & $5 \mathrm{kDa}, 6-8$ conserved cystein residues, toxic to plant pathogens and fungi. \\
\hline
\end{tabular}

Abbreviations: CNS, central nervous system; GIT, gastrointestinal tract; HIV, human immunodeficiency virus; MRSA, methicillin-resistant S. aureus; TMV, tobacco mosaic virus.

Ribosomally synthesized antibiotic peptide as mitogens

Initial evidence that antimicrobial peptides could possess mitogenic properties was provided by Murphy et al. ${ }^{24}$ Defensins may perform a double role in skin injuries. Besides preventing microbial infection, they may also be involved in a wound healing process, which was found to be mediated by the mitogen-activated protein kinase pathway. The presence and expression of antimicrobial peptides is not restricted to particular cells or surfaces, as exemplified by granulocytes and epithelial cells in mammals. Moreover, biopsies of renal carcinoma tissue revealed the intracellular expression of these defensins and renal carcinoma cell lines studied in vitro demonstrated that defensins were present at a concentration not exceeding $25 \mu \mathrm{g} \mathrm{ml}^{-1}$, which stimulated DNA synthesis. ${ }^{25}$ This may suggest a possible role of defensin proliferation of either normal or tumor cells in the kidney.
A cathelicidin was found first in the skin during analysis of wound fluid components. ${ }^{26}$ Porcine wound fluid contains high levels of a molecule that induces synthesis of syndecans-1 and 4, proteoglycans involved in key aspects of wound repair. Purification and sequencing of this molecule revealed a peptide identical to proline/arginine-rich cathelicidin PR-39, an antimicrobial molecule previously identified in the pig gut and neutrophil azurophilic granules. $^{27}$

The expression of a second cathelicidin, LL-37, was found in keratinocytes of human skin having inflammation. LL-37 is expressed at involved sites of psoriasis, nickel contact dermatitis and systemic lupus erythematosus. The absence of detectable LL-37 expression in uninflamed skin, suggested that this antimicrobial peptide functions mainly in injured cells rather than in modulating the surface colonization of an intact epithelium. ${ }^{28}$ 
Table 2 Other sources of anionic ribosomally synthesized antimicrobial peptides

\begin{tabular}{|c|c|c|}
\hline Name & Sources & Characteristics \\
\hline Aromatic dipeptides & $\begin{array}{l}\text { Dipteran larvae, flesh } \\
\text { fly, saw fly }\end{array}$ & $573 \mathrm{Da}$, low MW. \\
\hline $\begin{array}{l}\text { Aspartic acid-rich } \\
\text { molecules }\end{array}$ & $\begin{array}{l}\text { Cattle pulmonary } \\
\text { surfactants }\end{array}$ & $\begin{array}{l}\text { Similar to charge-neutralizing } \\
\text { propeptides, regulate activity } \\
\text { of pulmonary enzyme systems } \\
\text { in animals. }\end{array}$ \\
\hline Citropins & $\begin{array}{l}\text { L. citropa, Australian } \\
\text { Blue Mountain tree frog }\end{array}$ & $\begin{array}{l}\text { 16, Simplest amphibian wide- } \\
\text { spectrum antibacterial } \\
\text { peptides. }{ }^{144}\end{array}$ \\
\hline $\begin{array}{l}\text { Neuropeptide-derived } \\
\text { molecules }\end{array}$ & $\begin{array}{l}\text { Infectious exudates of } \\
\text { cattle and humans }\end{array}$ & $\begin{array}{l}\text { From processed neuropeptide } \\
\text { precursor to yield active pep- } \\
\text { tide B and enkelytin, some are } \\
\text { phosphorylated. }\end{array}$ \\
\hline Oxygen-binding proteins & $\begin{array}{l}\text { Hemolymph of arthro- } \\
\text { pods and annelids, tick } \\
\text { hemolymph }\end{array}$ & $\begin{array}{l}\text { Derived from hemocyanin } \\
\text { derivatives. }\end{array}$ \\
\hline
\end{tabular}

Table 3 Other sources of neutral ribosomally synthesized antimicrobial peptides

\begin{tabular}{|c|c|c|}
\hline Name & Sources & Characteristics \\
\hline Alloferron & $\begin{array}{l}\text { Calliphora vicina, } \\
\text { blow fly }\end{array}$ & $\begin{array}{l}13, \text { Rich in glycine and histidine, } \\
\text { active against viruses and cancer } \\
\text { cells. }{ }^{145}\end{array}$ \\
\hline Andropin & $\begin{array}{l}\text { Drosophila melanogaster, } \\
\text { fruit fly }\end{array}$ & $\begin{array}{l}34 \text {, Expressed in the adult male } \\
\text { ejaculatory duct, less fungicidal than } \\
\text { cercopins, inhibits Gram-positive } \\
\text { bacteria. }{ }^{146}\end{array}$ \\
\hline Gramicidin A & $\begin{array}{l}\text { Bacillus brevis, soil } \\
\text { bacteria }\end{array}$ & $\begin{array}{l}\text { 15, Helix, active for HIV and HSV } \\
\text { infections other than Gram-positive } \\
\text { and Gram-negative bacteria. }\end{array}$ \\
\hline Kalata B1 & $\begin{array}{l}\text { Oldenlandia affinis, } \\
\text { African herb }\end{array}$ & $\begin{array}{l}29 \text {, Beta, G6 is critical to bind } \\
\text { phosphatidyl ethanolamine, active } \\
\text { against viruses, insects, HIV and } \\
\text { mammalian cells. }{ }^{147}\end{array}$ \\
\hline
\end{tabular}

\section{Antitumor activity}

A growing number of studies have shown that some of the cationic antimicrobial peptides, which are toxic to bacteria but not to normal mammalian cells, exhibit a broad spectrum of cytotoxic activity against cancer cells. Such studies have considerably enhanced their significance, both synthetic and from natural sources, which have been of importance both for an increased understanding of the immune system and for their potential as clinical antibiotics. The basic difference between the cell membranes of malignant cells and normal cells accounts for the ability of certain antimicrobial peptides to show cytotoxic effects against the cancer cells (anticancer peptides) without causing any harm to the healthy cells. ${ }^{29}$ Antimicrobial peptides have the capacity to interact with the negatively charged molecules that are present in the target, but tumor cells are different in their membrane composition. ${ }^{30}$ The membrane fluidity of cancer cells is greater than that of untransformed cells, which may enhance the lytic activity of anticancer peptides by facilitating membrane destabilization. A large number of microvilli on the surface of cancer cells accounts for the greater surface area than normal cells; this may allow them to bind to higher number of anticancer peptides. The microvilli are also more irregular in size and shape, which may be due to changes in structural proteins. ${ }^{29}$ Defensins are also found to be effective against tumor cells by inducing tumor cell lysis, so the replacement of certain amino acids from $\mathrm{L}$ to $\mathrm{D}$ isomers in the peptide chain or modifying the peptide terminal (for example, amidation) will solve the problem and increase the compound's tumoricidal activity. ${ }^{31}$ Putting the gene coding for the ribosomally synthesized antimicrobial peptide into the tumor cell can avoid this type of loss in activity.

Magainins are a group of cationic peptides derived from the skin of amphibians that are able to lyse many types of tumor cells at a concentration 5-10 folds lower than that for normal cell lysis. ${ }^{32}$ Baker et $a .^{33}$ showed that magainin2 and magainins synthetic analogs exerted their antitumor activity toward murine ascites tumors, leukemia and spontaneous ovarian tumor cells, both in vitro and in vivo. All D-amino-acid analogs of magainin were found to be as effective as doxorubicin toward ovarian tumor cells. Insect-derived peptides, cecropins, are also able to lyse tumor cells. In vitro experiments proved their effectiveness in cell lines with multidrugresistant phenotypes, where they destroyed tumor cells within $1 \mathrm{~h}$. Expression of antimicrobial peptides has been reported in several tumor cell lines, where depending on their concentrations, they exert mitogenic or necrotic activity. ${ }^{31}$

\section{MECHANISM}

Many antimicrobial peptides bind in a similar manner to negatively charged membranes and permeate them, resulting in the formation of a pathway for ions and solutes, but before reaching the phospholipid membrane it should cross the outer wall of the bacteria containing polysaccharides. However, a key weakness is that cationic charge leads to early recognition that salts close to physiological concentrations block antimicrobial peptide interaction with negatively charged surface groups. ${ }^{34}$ In this mechanism, the peptides initially interact with the surface lipopolysaccharides, competitively displacing the divalent polyanionic cations and partly neutralize lipopolysaccharides. This causes disruption of the outer membrane and peptides pass through the disrupted outer membrane and reach the negatively charged phospholipid cytoplasmic membrane. The membrane-active properties of such peptides have been extensively studied using model membranes.

The interactions between an antimicrobial peptide and membranes, can be studied either by an in vivo approach using intact cells or, alternatively, by extensive use of the in vitro experiments with isolated or model membranes. Ribosomally synthesized peptides interact with microbial membranes, resulting in two possible modes of action, depending on the peptide and the microbial species. The peptides can be membrane-disruptive resulting in cell lysis or, alternatively, membrane interaction can lead to the formation of transient pores and the transport of peptides inside the cell, bringing them into contact with intracellular targets. Three models of peptide insertion and membrane permeabilization are reported: toroidal pore, carpet and barrel stave (helical bundle model). Following attraction, $\alpha$-helical peptide, $\beta$-sheet peptides and $\theta$-defensins are inserted into the lipid bilayer in accord to the peptide/lipid ratio and to one of these three models (reviewed by Brodgen). ${ }^{35}$ In the 'toroidal-pore model', $\alpha$-helices of antimicrobial peptides such as magainin, protegrin and melittin insert into the membrane and induce lipid monolayers to bend continuously through the pore so that the water core is lined by both the inserted peptides and the lipid-head groups. In the 'carpet model', antimicrobial peptides accumulate on the lipid 
Table 4 Amino-acid sequence of the peptides

\begin{tabular}{|c|c|c|}
\hline Origin & $\begin{array}{l}\text { Name } \\
\text { (antimicrobial peptide) }\end{array}$ & Amino-acid sequence \\
\hline \multirow[t]{33}{*}{ Cationic } & Abacin & YVPLPNVPQPGRRPFPTFPGQGPFNPKIKWPQGY \\
\hline & Antiviral protein $Y 3$ & $\begin{array}{l}\text { AACARFIDDFCDTLTPNIYRPRDNGQRCYAVNGHRCDFTVFNTNNGGNPIRASTPNCKTVLRTAANRCPTGGRG } \\
\text { KINPNAPFLFAIDPNDGDCSTNF }\end{array}$ \\
\hline & Bactenecin & RLCRIVVIRVCR \\
\hline & Bactericidin B2 & WNPFKELERAGQRVRDAVISAAPAVATVGQAAAIARG \\
\hline & Brevinin & FLPVLAGIAAKVVPALFCKITKKC \\
\hline & Buforins & AGRGKQGGKVRAKAKTRSSRAGLQFPVGRVHRLLRKGNY \\
\hline & Carein 1.1 & GLLSVLGSVAKHVLPHVVPVIAEHL \\
\hline & Catestatin & SSMKLSFRARAYGFRGPGPQL \\
\hline & Dermaceptin B2 & GLWSKIKEVGKEAAKAAAKAAGKAALGAVSEAV \\
\hline & Drosocin & GKPRPYSPRPTSHPRPIRV \\
\hline & ECAMP 1 & GSGRGSCRSQCMRRHEDEPWRVQECVSQCRRRRGGGD \\
\hline & ECAMP 2 & DRCSQQCQHHRDPDRKQQCMRECRRHQGRSD \\
\hline & EcLTP & AISCGQVSSAIGPCLSYARGQGSAPSAGCC \\
\hline & Esculentin 1 & GIFSKLGRKKIKNLLISGLKNVGKEVGMDVVRTGIDIAGCKIKGEC \\
\hline & Gomesin & ECRRLCYKQRCVTYCRGR \\
\hline & Heliomicin & DKLIGSCVWGAVNYTSDCNGECKRRGYKGGHCGSFANVNCWCET \\
\hline & Hepcidin-25 & DTHFPICIFCCGCCHRSKCGMCCKT \\
\hline & Hydramacin & $\begin{array}{l}\text { MRSIVGFIFVSIFLVALMPSDTQAGTLLGCWETWSRCTKWSQRGTGILWKNCNNRCKELGHSSGL } \\
\text { CEKRRSKCRFSKNAWACICY }\end{array}$ \\
\hline & Maximin 1 & GIGTKILGGVKTALKGALKELASTYAN \\
\hline & Melittin & GIGAVLKVLTTGLPALISWIKRKRQQ \\
\hline & Meucin & Meucin-13-IFGAIAGLLKNIF-NH2 \\
\hline & & Meucin-18-FFGHLFKLATKIIPSLFQ \\
\hline & Oncorhyncin & MPKRKSATKGDEPARRSARLSARPVPKPAAKPKKAAAPKKAVKGKKAAENGDAKAEAKVQAAGDGAGNAK \\
\hline & Parasin I & KGRGKQGGKVRAKAKTRSS \\
\hline & Paenibacillin & ASIIKTTIKVSKAVCKTLTCICTGSCSNCK \\
\hline & Perinerin & FNKLKQGSSKRTCAKCFRKIMPSVHELDERRRGANRWAAGFRKCVSSICRY \\
\hline & Ponericin G1 & GWKDWAKKAGGWLKKKGPGMAKAALKAAMQ \\
\hline & PW2 & HPLKQYWWRPSI \\
\hline & Pyrrhocoricin & VDKGSYLPRPTPPRPIYNRN \\
\hline & Ranalexin & FLGGLIKIVPAMICAVTKKC \\
\hline & Ranateurin & GLMDTVKNVAKNLAGHMLDKLKCKITGC \\
\hline & Tachyplesin I & KWCFRVCYRGICYRRCR \\
\hline & Temporin & FLPLIGRVLSGIL \\
\hline Anionic & Citropins & GLFDVIKKVASVIGGL \\
\hline \multirow[t]{4}{*}{ Neutral } & Alloferon & HGVSGHGQHGVHG \\
\hline & Andropin & VFIDILDKVENAIHNAAQVGIGFAKPFEKLINPK \\
\hline & Gramicidin A & VGALAVVVWLWLWLW \\
\hline & Kalata B1 & GLPVCGETCVGGTCNTPGCTCSWPVCTRN \\
\hline
\end{tabular}


bilayer surface, which are orientated in the plane of membrane. When high concentration is attained, peptides re-orient and their aggregates get inserted into the membrane and disrupt it by producing micelles in a detergent-like manner. Antimicrobial peptides that act by the 'carpet model' are represented by cecropin, dermaseptin and melittin. Finally, in the 'barrel-stave model', antimicrobial peptide $\alpha$-helices form a bundle in the membrane, where the hydrophobic stretches of inserted peptides align with the lipid core region of the bilayer, and the hydrophilic peptide stretches form the pore lining. Thus, these three mechanisms contribute to form pores, channels and to provoke membrane disruption and cell killing. ${ }^{36}$ Certain peptides may also be actively taken up by transporters. ${ }^{35,37}$ Antimicrobial peptides can have multiple intracellular targets. They can bind DNA, RNA and proteins, inhibit cell wall synthesis and DNA, RNA or protein synthesis. ${ }^{38-40}$ FtsZ, a conserved tubulin-like bacterial protein critical for division septum formation, has recently been identified as the intracellular target for an antimicrobial peptide. ${ }^{41}$ Other known intracellular targets of antimicrobial peptides are DNA gyrase and the heatshock protein DnaK. In addition, some peptides have non-protein targets such as the peptidoglycan precursor lipid II. ${ }^{42,43}$

\section{ANTIBIOTIC RESISTANCE}

Microbes can occupy and exploit a vast variety of tissues and niches, but still microbial pathogens may be able to resist antimicrobial peptides. This can happen by constitutive (passive) or inducible (adaptive) mechanisms. The constitutive mechanism is an inherent property of the microorganisms and is expressed normally even when the peptides are not present in the vicinity. Many microorganisms resist killing by diverse types of microorganisms, for example, Serratia sp., Proteus sp. and Burkholderia sp. This may be due to the stable structure or functional property or pathogenesis. Cashman et al. ${ }^{44}$ demonstrated that Enterococcus species exhibit broad resistance to a panel of cationic antimicrobial peptides and heavy metal ions. Furthermore, these investigators identified an inverse correlation between glycopeptide susceptibility and resistance to cationic antimicrobial peptides or oxidized metal ions among enterococcal clinical isolates.

Inducible mechanism or resistance is triggered in response to the antimicrobial peptide or any kind of stress caused due to them. Many pathogenic microbes have to come across a number of host defense systems and they have to deal with them in order to survive and grow. So many of them have evolved some or the methods to protect themselves from these systems. For example, in bacteria, inducible resistance to antimicrobial peptides is largely controlled through sophisticated sensor-transducer response systems. Among the first to observe this phenomenon were Fields et al., ${ }^{45}$ who determined that a specific genetic locus of the pathogen Salmonella typhimurium is integral to intracellular survival in macrophages and virulence in mice by conferring resistance to a defensin peptide. Oh et al. ${ }^{46}$ demonstrated that sublethal levels of cecropins induce hyperosmotic stress response systems in Escherichia coli. However, sublethal concentrations of cecropin A prompted a pattern of genomic responses in $E$. coli that is distinguishable from that induced by lethal concentrations, and distinct from bacterial stress response systems such as heat-shock, hyperosmotic or oxidative response paradigms. The following (Figure 1$)^{47}$ shows the various mechanisms of resistance.

Human antimicrobial peptide LL-37 induces the mefE promoter and confers resistance to erythromycin and LL-37. Macrolide resistance is a major concern in the treatment of Streptococcus pneumoniae. Inducible macrolide resistance in S. pneumoniae is mediated by the efflux pump MefE/Mel. The MefE/Mel efflux pump can further contribute to cathelicidin resistance and may thereby contribute to increased survival in the human host. ${ }^{48}$ In Drosophila, the antifungal response is induced by the toll signaling pathway that is very similar to the dorso-ventral morphogenic pathway as well as to the acute phase response in mammals, which involves the cytokine interleukin-1. The antibacterial response involves a less extensively characterized imd gene (immune deficiency gene) system. In pigs cathelicidins are responsible to avoid bacterial proliferation in skin wounds. ${ }^{49}$

\section{NATURAL ALTERNATIVE TO CHEMICAL ANTIBIOTICS}

Antimicrobial peptides are a defense mechanism that can remain over long evolutionary time spans and can act rapidly to neutralize a broad range of microorganisms, such as bacteria, fungi and viruses. ${ }^{50}$ The most common mechanism of action against bacteria is the so-called 'carpet' mechanism, in which the peptide accumulates on the bacterial membrane up to a threshold concentration causing permeabilization/ disintegration..$^{51}$

In case of neonatal diarrheal disease in cattle, host defense antimicrobial peptides present in body secretions, such as tears and saliva, are naturally active against bacteria, viruses and parasites. They also stimulate an immune response against an infectious disease. ${ }^{52}$ Unlike antibiotics, these are not specific to a particular disease, thus protect against a number of pathogens. Similarly, bacteriocins produced by many bacteria, for example, lactic acid bacteria (LAB) (produce a high diversity of bateriocins), can target many food pathogens such as E. coli and Salmonella without affecting any other parameters of food. Moreover, consumption of food that is chemically preserved has created a need for more safe and naturally preserved food.

\section{SOURCES OF RIBOSOMALLY SYNTHESIZED ANTIMICROBIAL PEPTIDES \\ Bacteria}

A wide range of bacteria are found to produce antimicrobial peptides. The peptides produced by bacteria are also termed 'bacteriocins. ${ }^{47}$ $\mathrm{LAB}$ can produce a number of ribosomally synthesized proteins and peptides, which have antimicrobial activity to compete with other bacteria of the same species as well as of other genera. The first description of bacteriocin-mediated growth inhibition was reported 85 years ago, when antagonism between strains of $E$. coli was first discovered. ${ }^{53}$ The inhibitory substances were called 'colicins', to reflect the producer organism, whereas gene-encoded antibacterial peptides produced by bacteria are now referred to as 'bacteriocins'. Some of the bacteriocins being produced by LAB are listed in the Table 5 below. ${ }^{54}$

$\mathrm{LAB}$ also produces acidocin that is active against meticillin-resistant S. aureus and C. difficile, which are common hospital pathogens. All the antimicrobial peptides produced by LAB are heat stable, active at $\mathrm{pH} 3$ to 6.5 and are effective against a number of Gram-positive and -negative pathogens. Several bacteriocins are produced by enterococci, especially by E. faecium. Till now, many enterocins from $E$. faecium have been characterized: enterocin $\mathrm{A},{ }^{55}$ enterocin $\mathrm{B},{ }^{55}$ enterocin $\mathrm{P},{ }^{56}$ enterocin $I^{57}$ enterocin $Q^{58}$ and enterocin $M$ (a new variant of enterocin P). ${ }^{59}$ In general, most enterocins belong to the class $2 \mathrm{a}$ bacteriocins, are like pediocin and are thermostable.

Peptides derived from bacteria are important antimicrobial compounds owing to their inherent ability to defend against potential pathogens and their low toxicity in mammalian cells. ${ }^{60}$ The iturin and bacillomycin families produced by Bacillus species and viscosin, amphisin, tolaasin and syringomycin produced by Pseudomonas sp. all have cyclic peptidolipid structures and display antimicrobial 


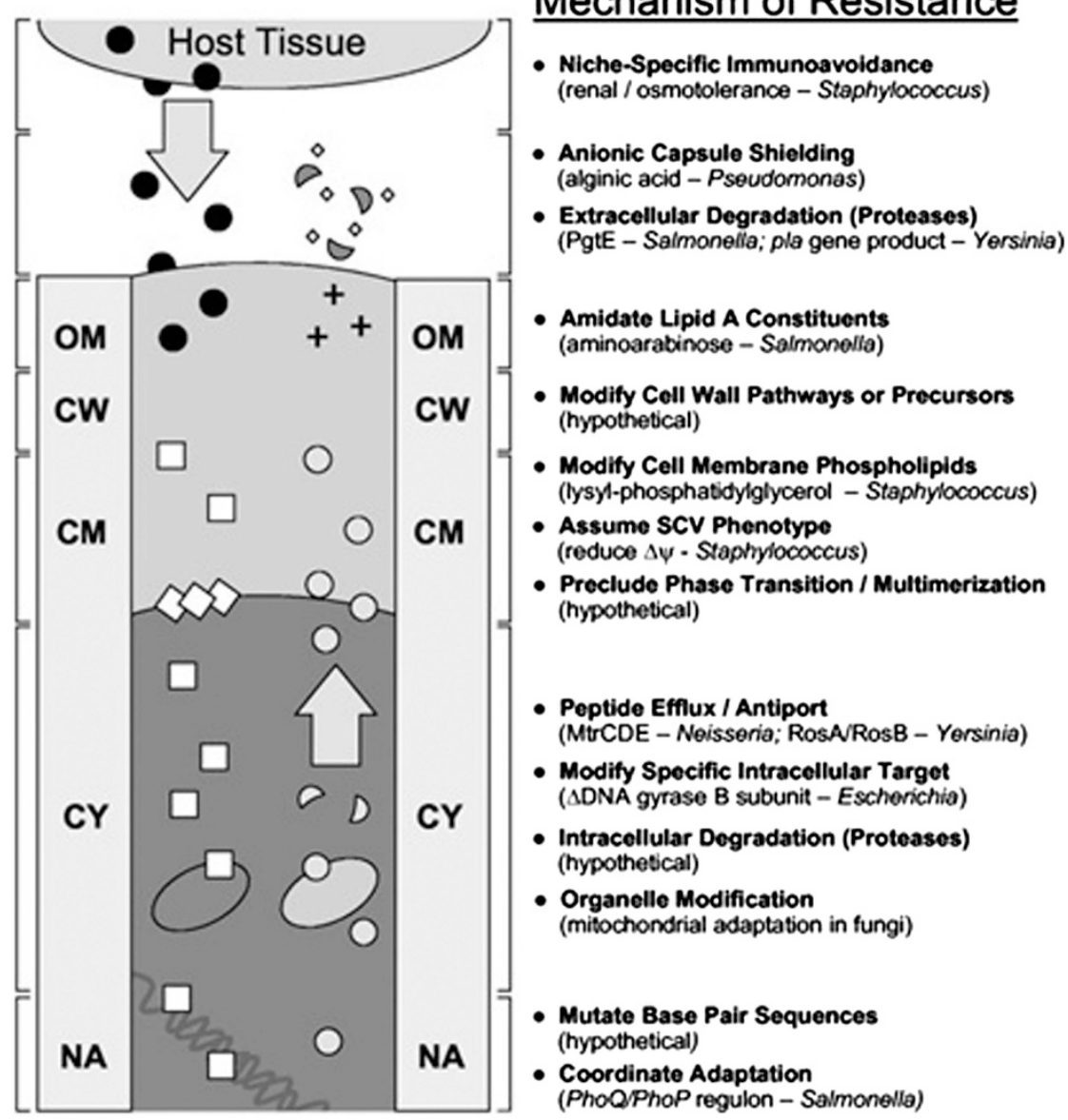

Figure 1 Parallels in antimicrobial peptide mechanisms of action and resistance. OM, outer membrane; CW, cell wall; CM, cytoplasmic membrane; $\mathrm{CY}$, cytoplasm; NA, nucleic acid. Specific examples of mechanisms of action or resistance, listed in parenthesis are representative only and not to be considered exhaustive. ${ }^{47}$

activity against a wide range of plant pathogens. ${ }^{61}$ Brevibacillus laterosporus, previously classified as $B$. laterosporus, ${ }^{62}$ can produce different virulence factors: parasporal crystalline, ${ }^{63}$ extracellular protease ${ }^{64}$ and lipopeptide antibiotics. ${ }^{65}$ In addition, B. laterosporus also secretes short-sequence peptides with broad antibiotic spectra, such as loloatin A. ${ }^{66}$ These antimicrobial peptides show thermostability in antimicrobial activity $\left(90 \%\right.$ activity at $100{ }^{\circ} \mathrm{C}$ for $\left.15 \mathrm{~min}\right)$ and are unaffected by protease $\mathrm{K}$, trypsin and pepsin after $60 \mathrm{~min}$ at $28^{\circ} \mathrm{C}^{67}$ They are also of low MW and stable at vast $\mathrm{pH}$ range.

There are several spermicidal antimicrobial peptides being produced by bacteria such as Gramicidin A produced by the soil bacteria $B$. brevis. It is the first peptide antibiotic used clinically. It is 15-amino-acid long and helical in shape, synthesized non-ribosomally by a multienzyme complex. It is active against HIV and HSV infections along with Gram-positive, Gram-negative bacteria and other viruses. Amino acids 4,6,8,10 and 12 are D-forms, allowing formation of a special helical structure that dimerizes into a cation channel in the lipid bilayer with the C-terminal exposed. ${ }^{68}$ Another peptide produced by $B$. subtilis, known as subtilosin $\mathrm{A}$ is also a 35 -amino-acid helix containing an $\mathrm{N}$ and $\mathrm{C}$-circulated peptide. It also contains three rare crosslinks between the $S$ of cystein 13,7 and 4 and $\alpha-C$ of phe 22, thre 28 and phe 31 . It shows chemical modifications and three thioether links. ${ }^{69}$ Similarly a peptide known as lacticin 3147 produced by Lactococcus lactis also comes in the spermicidal group with 30 amino acids, where two polypeptide chains work synergistically. When it comes in contact with bacteria, A1 first binds to lipid II followed by binding of chain A2 leading to pore formation. ${ }^{70}$

\section{Fungi}

Plectasin is the first defensin to be isolated from a fungus, the saprophytic Ascomycete Pseudoplectania nigrella. Plectasin has primary, secondary and tertiary structures that closely resemble those of defensins found in spiders, scorpions, dragonflies and mussels. Recombinant plectasin was produced at a very high and commercially viable yield and purity. Aspergillus clavatus ESI produces a peptide AcAMP with high thermostability and antibacterial property. It is $6.0 \mathrm{kDa}$ and shows characteristics common to the group of small, basic, cysteine-rich antifungal proteins from molds. ${ }^{71}$ It is also $\mathrm{pH}$ tolerant and active against bacteria and fungi. The open-reading frame is of $282 \mathrm{bp}$ encoding a peptide of 94 amino-acid residues consisting of a 21-amino-acid signal peptide, a 22-amino-acid pro-peptide and a 51-amino-acid mature peptide.

\section{Protozoans}

Several antimicrobial peptides in Hydra, a simple Eumetazoan organism, living in fresh water ponds is found to possess antimicrobial peptides, which are highly active against human pathogenic bacteria. Hydra holds promise for the detection of novel antimicrobial molecules and the treatment of infections caused by the multiresistant bacteria. Hydramacin from $H$. vulgaris is isolated as a 
Table 5 Classification of bacteriocins produced by lactic acid bacteria ${ }^{54}$

\begin{tabular}{lll}
\hline Category & Subcategory & Characteristics \\
\hline $\begin{array}{l}\text { Class } 1 \\
\text { Lantibiotics, lanthionine }\end{array}$ & Type A & Elongated molecules: molecular mass <4 kDa \\
Containing & Type B & Globular molecules: molecular mass 1.8-2.1 kDa \\
Class 2 & Subclass 2a & Molecular mass $<10 \mathrm{kDa}$ \\
Non-modified heat-stable bacteriocins & Subclass 2b & \\
& Subclass 2c & Molecular mass $>30 \mathrm{kDa}$
\end{tabular}

Protein bacteriocins

disulfide bridge-stabilized $\alpha \beta$ motif, which is a scaffold of knottin protein fold.

Arminin la is a novel antimicrobial peptide discovered during investigations of the epithelial defense of the ancient metazoan Hydra. It is 31-amino-acid long, positively charged and the C-terminal part of arminin la exhibits potent and broad-spectrum activity against bacteria, including multidrug-resistant human pathogenic strains, such as methicillin-resistant $S$. aureus strains. Arminin la is a selective antibacterial agent that does not affect human erythrocyte membranes. It shows no sequence homology to any known antimicrobial peptide, ${ }^{72}$ making it a candidate for further studies regarding antimicrobial properties.

\section{Insects}

There have been a number of antimicrobial peptides isolated from insects. Insect defensins are 36-46-amino-acid long with the exception of the 51 residue bee and bumblebee defensins. These include the phormicins, sapecins, royalisin and spodoptericin. Defensins, were first reported from cell cultures of the flesh fly Sarcophaga peregrine. Some of the antifungal defensins are as follows: drosomycin from Drosophila; heliomycin from the tobacco budworm Heliothis virecens (Lepidoptera), gallerimycin from the greater wax moth larvae Galleria mellonella (Lepidoptera), termicin from the isopteran P. spiniger and Alo13 from the harlequin beetle Acrocinus longimanus. ${ }^{73}$

Thanatin has been isolated from the spine soldier bug Podisus maculiventris containing 21 amino acids with a broad spectrum of activity, both Gram-positive and Gram-negative bacteria, filamentous fungi and yeasts without measurable toxicity for red blood cells. It is a novel therapeutic agent against multidrug-resistant bacteria because of its different modes of action, small size and non-toxicity to eukaryotic cells.

Linear proline-rich antimicrobial peptides are isolated from insects such as, abaecins and apidaecins from bees and wasps, formaecins from ants, drosocins and metchnikowins from the D. melanogaster, lebocins from the silkworm Bombyx mori, the cabbage looper moth Trichoplusiani, pyrrhocoricin and metalnikowins from bugs. ${ }^{73}$ Andropin is a peptide secreted by male ejaculatory duct of male D. melanogaster. It contains a hydrophobic amino terminus with striking similarity to the signal peptide of the cecropins. It is for the protection of the seminal fluid and the male reproductive tract against microbial infections. In Drosophila, the cecropin genes are found in a dense cluster of several genes and pseudogenes at $99 \mathrm{E}$ on the third chromosome, encoding at least two different types of cecropins. These are expressed mainly in the fat body and to some extent in hemocytes, and their antibacterial products accumulate in the hemolymph. ${ }^{74}$ Drosocin is a novel 19-residue proline-rich inducible antibacterial peptide from Drosophila. The peptide has an O-glycosylation that is necessary for its full biological activity.
Four antimicrobial peptides were purified from the royal jelly of honeybees, called jelleines (I-IV). They are capable of antimicrobial activity, mast cell degranulating activity and hemolysis. The Jelleines I-III present antimicrobial activity against both Gram-positive and negative bacteria. These peptides do not present any similarity with the other antimicrobial peptides from the honeybees and they are produced constitutively by the workers and secreted into royal jelly. ${ }^{75}$

Scorpion venom contains series of bioactive peptides, among which the antibacterial peptide is an important part, and a new antimicrobial peptide StCT2 is characterized from the venomous gland cDNA library of the Scorpiops tibetanus. ${ }^{76}$ It is active against methicillin-resistant $S$. aureus, methicillin-resistant coagulase-negative Staphylococci and penicillin-resistant S. aureus and has both cationic and amphiphilic nature.

\section{Fishes}

The peptide antibiotics isolated from fish, reside in mast cells, an immune cell of uncertain function. Piscidins from the tissues of an important aquacultured fish, hybrid striped bass (Morone saxatilis and M. chrysops). Piscidins are 22-amino-acid peptides with a highly conserved amino terminus that is rich in histidine and phenylalanine. The peptides probably adopt an amphipathic $\alpha$-helical conformation. Piscidins have potent, broad-spectrum antibacterial activity against fish pathogens, which is comparable to that of many peptides from aquatic animals. A $6.7 \mathrm{kDa}$ antimicrobial peptide was isolated from trout skin secretions. The peptide is a potent antibacterial agent against both Gram-positive and -negative bacteria and is sensitive to $\mathrm{NaCl}$.

Parasin I isolated from catfish Parasilurus asotus has a MW of 2000.4 Da, strong antimicrobial activity and has no hemolytic ability. It is 19 residues long and produced only when the fish is injured. Another antimicrobial peptide named Misgurin is isolated from loach, Misgurnus anguillicaudatus. It has 21 amino acids with a weight of $2502 \mathrm{Da}$ and binds specifically to negatively charged phospholipids.

The cod cathelicidin antimicrobial peptide was isolated from the head and kidney of the Atlantic cod Gadus morhua, 67 amino acids long with serine, arginine and glycine predominance. It acts through rapid lysis of bacterial cells.

\section{Amphibians}

Tachyplesins and their analogs are antimicrobial peptides composed of 17 or 18 amino-acid residues present abundantly in acid extracts of hemocyte debris of horseshoe crabs. Tachyplesins is isolated from two species of southeast Asian horseshoe crab Carcinoscorpius rotundicauda and Tachypleusgigas gigas. Ranalexin is a novel antimicrobial peptide from the bullfrog $R$. catesbeiana. It is structurally similar to polymyxin. 
Nineteen citropin peptides are present in the secretion from the granular dorsal glands of the Blue Mountain tree frog Litoria citropa; 15 of these peptides are also present in the secretion from the submental gland. Two major peptides, citropin 1.1, citropin 1.2 and a minor peptide, citropin 1.3 are wide-spectrum antibacterial peptides. Citropin 1.1 is an amphipathic $\alpha$-helix with well-defined hydrophobic and hydrophilic regions. ${ }^{77}$ These peptides show minimal antibacterial activity; their role in the amphibian skin is not known.

\section{Reptiles}

Cathelicidin-like antimicrobial peptide, named cathelicidin-BF, was isolated from the crude venom of the snake Bungarus fasciatus, commonly known as banded krait and the peptide sequence was characterized. It exerts strong and rapid antimicrobial activities against many microorganisms including Gram-negative, Gram-positive bacteria and fungi, especially some clinically isolated drugresistant microorganisms. Besides, cathelicidin-BF has no hemolytic and cytotoxic activity on human cells. ${ }^{78}$ It could significantly inhibit Propionobacterium acnes, induced secretion of several proinflammatory factors including TNF- $\alpha$, interleukin-8, interleukin- $1 \mathrm{~b}$ and MCP-1.

Naja antimicrobial peptide purified from Naja naja venom is a potent antibacterial agent against Gram-negative organisms such as E. coli, P. aeruginosa and Vibrio cholerae, and Gram-positive bacterial strains such as S. aureus, E. faecalis, S. pneumoniae, S. pyogenes and $B$. subtilis. The most potent activity was toward Gram-negative bacteria. The amphipatic alpha-helical conformation has an important role in their biological activities. ${ }^{79}$

\section{Aves}

Five bactericidal peptides (chicken heterophil peptides CHP1 and CHP2; turkey heterophil peptides THP1, THP2 and THP3) are purified from avian heterophil granules. All peptides are cationic and rich in cysteine, arginine and lysine. The complete amino-acid sequence, consist of 39 amino acids, as determined for CHP1. This peptide had a MW of 4481. They have antibacterial properties against E. coli and S. aureus. These peptides were extracted from cells pooled from numerous birds. ${ }^{80}$

Common pheasant Phasianus colchicus gives three deduced mature cathelicidin antimicrobial peptides, Pc-CATH1, 2 and 3 that are composed of 26, 32 and 29 amino-acid residues, respectively. Unlike the mammalian cathelicidins that are highly divergent even within the same genus, it shows hemolytic activity and serum stability. Yak alsi produces a peptide from polymophonuclear leukocytes (PMN). The crude extraction from PMN was isolated, respectively, through a method of extraction by using $5 \%$ acetic acid. The crude extraction showed feeble hemolysis activity to red blood cells of sheep and rabbit. The crude extraction from PMN of yak showed feeble hemoblast anticoagulation activity to blood cell of rabbit, whereas to blood cell of sheep, they were less effective.

\section{Mammals}

Humans express only one cathelicidin, a prepropeptide called hCAP18. LL-37, a 37-residue $\alpha$-helical peptide at the carboxy-terminal domain of hCAP-18, is released after hCAP-18 is processed by neutrophil elastase. Human cathelicidin antimicrobial peptide, LL37 , is shown to exhibit potent activity against microbes and is salt sensitive. Protegrins are small $(\sim 2 \mathrm{kDa})$ broad-spectrum antimicrobial peptides found in porcine neutrophils, where they are stored as cathelin-containing precursors. Mature, fully processed protegrins contain 16-18 amino-acid residues and are released from their precursors by neutrophil elastase. ${ }^{81}$ Unlike the larger defensins, protegrins retain activity in physiological concentrations of sodium chloride, whereas truncated protegrins with 12 residues manifest potent antibacterial activity.

Granulysin, a peptide stored in the cytoplasmic granules of human natural killer cells and cytolytic T cells, was shown to kill Mycobacterium tuberculosis. The combination of granulysin and perforin-like molecules may equip $\mathrm{T}$ cells to kill many intracellular pathogens. Histatins are small, histidine-rich, human salivary proteins that display moderate activity against Candida albicans, especially at an acidic $\mathrm{pH}$, under conditions of relatively low ionic strength. Because histatins have little or no toxicity and are active against azole-resistant fungal species, there are considerable efforts to design histatin-like peptides with enhanced activity and stability. ${ }^{82}$ Histatins are not obviously membranolytic, and histatin-mediated killing may be mediated by binding to a $67-\mathrm{kDa} C$. albicans protein, which is found in lysates and crude membrane fractions. ${ }^{83}$

Antimicrobial beta-defensins, such as tracheal antimicrobial peptides in epithelial cells of the bovine respiratory tract and lingual antimicrobial peptides in the tongue, are stimulated by lipopolysaccharides, interleukin-1b and tumor necrosis factor. Defensins are widely distributed in mammalian epithelial cells and phagocytes, often in high concentrations. Other antimicrobial peptides are restricted to a few animal species and tissues, such as histatins, dermicidins and anionic peptides.

\section{Plants}

Thionins constitute a family of basic peptides ( $\mathrm{pI}>8$ ), with low MW $(\sim 5 \mathrm{kDa})$, rich in basic and sulfur-containing residues (arginine, lysine and cysteine). Its diverse members have high sequential and structural similarities besides presenting toxic effects against bacteria, fungi, yeast and animal and plant cells. $\alpha$-Purothionins are extracted from flour milled from hexaploid wheat. The $\alpha 1$ and $\alpha 2$ purothionin molecules each consists of 45 amino acids differing only at six positions. $^{84}$

Plant defensins, which are also known as $\gamma$-thionins, are one of the most important and very well-studied class of antimicrobial peptides. With an approximate size of $5 \mathrm{kDa}$, they have been reported to show inhibitory activities against fungi, bacteria and insects. All plant defensins share a typical three-dimensional folding pattern, stabilized by four disulfide bridges, that incorporate the cysteine-stabilized $\alpha \beta$ motif. The first floral defensin that was characterized structurally by NMR was $\mathrm{NaD} 1$, isolated from Nepenthes alata.

Lipid transfer proteins, a family of proteins is characterized by facilitating the lipid transfer among natural or artificial membranes and by linking to fatty acids in vitro. Owing to the accumulated information about plant lipid transfer proteins, various functions have been suggested for this family of proteins, as well as its participation in cuticle formation and embryogenesis. ${ }^{85}$

\section{CHALLENGES IN DEVELOPMENT OF RIBOSOMALLY SYNTHESIZED ANTIMICROBIAL PEPTIDES}

Antimicrobial peptides have high level of chemical and biological diversity, are highly specific and are difficult to identify in a specific screen. They are small, but the amount of antimicrobial peptides required is much more compared with antibiotics. ${ }^{86}$ Their potency is also not as strong. Although they do have good in vitro effects, they may have different in vivo effects as peptides with L-amino acids are potential immunogens. ${ }^{87}$ They are active against multidrug-resistant strains at similar concentrations, are rapid and involve multiple targets, still production cost is not economically feasible and is nearly 
5-20 times higher than typical antibiotic drugs. There is also a lack of knowledge in thoroughly examining the systemic peptide, pharmacodynamics and pharmacokinetics, thus its not patient compliant.

In the process of developing, the half-life of a peptide is very important and can be extended by modifications such as glycosylation, conjugation and converting D-forms of amino acids to L-forms. ${ }^{88}$ For example, polyethylene glycol can conjugate with an amino acid and thus protect it from proteolysis by stearic hindrance. This can also be harmful, as more modification can lead to more resistance and thus avoid its contact with a specific target. Peptides may also be designed to fuse with serum albumin (as it is the most abundant protein in serum with 19 days life) with non-covalent association and increase the half-life.

The nanoparticle approach can also be followed to enhance the effect and make it economical. The biomolecule and nanoparticle hybrid system is highly active, stable and an efficient alternative to enhance their therapeutic application. ${ }^{88}$ It protects from degradation, enhances absorption by diffusion and, most importantly, the drugtargeting system can be given to a precise location, thus reducing the amount required and also the side effects, also making it economically feasible. Owing to small size, it is also possible to search for an alternative to give peptides i.v. Much more developments have to be done with respect to antimicrobial peptides or ribosomally synthesized antibiotic peptides.

\section{CONCLUSION}

Ribosomally synthesized antimicrobial peptides are a great answer to the problems caused by increasing drug resistance, as they have multiple functions against bacteria, fungi, cancer etc. As they are effective with both innate and adaptive immune responses, they are toxic to a number of pathogens. They are stable at a wide range of temperature and $\mathrm{pH}$ values making them an effective natural remedy to many diseases. Their synthesis and mode of action distinguishes them from clinical antibiotics. Moreover, microbes showing resistance to antibiotics are generally not resistant to them. Also they are safe to use, so can be used for various purposes such as food preservatives. Their multifunctional ability has increased the scope of exploiting their nature for the welfare of humans.

1 Lehrer, R. I., Szklarek, D., Ganz, T. \& Selsted, M. E. Correlation of binding of rabbit granulocyte peptides to Candida albicans with candidacidal activity. Infect. Immun. 49, 207-211 (1985)

2 Li, Y., Xiang, Q., Zhang, Q., Huang, Y. \& Su, Z. Overview on the recent study of antimicrobial peptides: origins, functions, relative mechanisms and application. Peptides 37, 207-215 (2012)

3 Hancock, R. E. \& Sahl, H. G. Antimicrobial and host-defense peptides as new antiinfective therapeutic strategies. Nat. Biotechnol. 24, 1551-1557 (2006).

4 Schneider, T. et al. Plectasin, a fungal defensin, targets the bacterial cell wall precursor lipid II. Science 328, 1168-1172 (2010).

5 Zasloff, M. Antimicrobial peptides of multicellular organisms. Nature 415, 389-395 (2002).

6 Armstrong, G. L., Conn, L. A. \& Pinner, R. W. Trends in infectious disease mortality in the United States during the 20th century. J. Am. Med. Assoc. 1, 61-66 (1999).

7 Walsh, C. Where will new antibiotics come from? Nat. Rev. Microbiol. 1, 65-70 (2003).

8 Projan, S. J. Why is big Pharma getting out of antibacterial drug discovery? Curr. Opin. Microbiol. 6, 427-430 (2003).

9 Shlaes, D. M. The abandonment of antibacterials: why and wherefore? Curr. Opin. Pharmacol. 3, 470-473 (2003).

10 Foster, K. R. Biomedicine. Hamiltonian medicine: why the social lives of pathogens matter. Science 308, 1269-1270 (2005).

11 Rakoff-Nahoum, S., Paglino, J., Eslami-Varzaneh, F., Edberg, S. \& Medzhitov, R. Recognition of commensal microflora by toll-like receptors is required for intestinal homeostasis. Cell 118, 229-241 (2004).

12 Hooper, L. V. et al. Molecular analysis of commensal host-microbial relationships in the intestine. Science 291, 881-884 (2001).
13 Liu, G. Y. et al. Staphylococcus aureus golden pigment impairs neutrophil killing and promotes virulence through its antioxidant activity. J. Exp. Med. 202, 209-215 (2005).

14 Hancock, R. E. W. Peptide antibiotics. Lancet 349, 418-422 (1997).

15 Falla, T. J., Karunaratne, D. N. \& Hancock, R. E. Mode of action of the antimicrobial peptide indolicidin. J. Biol. Chem. 271, 19298-19303 (1996).

16 Andreu, D. \& Rivas, L. Animal antimicrobial peptides: an overview. Biopoly 47, 415-433 (1998).

17 Charp, P. A. et al. Inhibition of protein kinase $\mathrm{C}$ by defensins, antibiotic peptides from human neutrophils. Biochem. Pharmacol. 37, 951-956 (1988).

18 Pogrebnoy, P. V. et al. A protein kinase inhibitor from A431 subline over expressing TGF alpha possesses antimicrobial activity. New Microbiol. 21, 269-273 (1998).

19 Blomqvist, M. et al. Identification of defensins in human Iymphocyte nuclei. Eur. J. Biochem. 263, 312-318 (1999).

20 Tanaka, K. et al. PI3-kinase p85alpha is a target molecule of proline-rich antimicrobial peptide to suppress proliferation of ras-transformed cells. Jpn J. Cancer Res. 92, 959-967 (2001)

21 Kirsch, K., Kensinger, M., Hanafusa, H. \& August, A. A p130Cas tyrosine phosphorylated substrate domain decoy disrupts v-crk signaling. BMC Cell Biol. 3, 18 (2002).

22 Fuqua, C. \& Greenberg, E. P. Self perception in bacteria: quorum sensing with acylated homoserine lactones. Curr. Opin. Microbiol. 1, 183-189 (1998).

23 Dunny, G. M. \& Leonard, B. A. Cell-cell communication in gram-positive bacteria. Annu. Rev. Microbiol. 51, 527-564 (1997).

24 Murphy, C. J., Foster, B. A., Mannis, M. J., Selsted, M. E. \& Reid, T. W. Defensins are mitogenic for epithelial cells and fibroblasts. J Cell Physiol. 155, 408-413 (1993).

25 Muller, C. A. et al. Human alpha-defensins HNPs-1, -2 , and -3 in renal cell carcinoma: influences on tumor cell proliferation. Am. J. Pathol. 160, 1311-1324 (2002).

26 Gallo, R. L. et al. Syndecans, cell surface heparan sulfate proteoglycans, are induced by a proline-rich antimicrobial peptides from wounds. Proc. Natl Acad. Sci. USA 91, 11035-11039 (1994).

27 Agerberth, B. et al. Isolation of three antibacterial peptides from pig intestine: gastric inhibitory polypeptide (7-42), diazepam-binding inhibitor (32-86) and a novel factor, peptide 3910. Eur. J. Biochem. 216, 623-629 (1993).

28 Frohm, M. et al. The expression of the gene coding for the antibacterial peptide LL-37 is induced in human keratinocytes during inflammatory disorders. J. Biol. Chem. 272, 15258-15263 (1997).

29 Chaudhary, J. \& Munshi, M. Scanning electron microscopic analysis of breast aspirates. Cytopathology 6, 162-167 (1995).

30 Kamysz, W., Okrój, M. \& Lukasiak, J. Novel properties of antimicrobial peptides. Acta Biochim. Pol. 50, 461-469 (2003).

31 Moore, A. J., Devine, D. A. \& Bibby, M. C. Preliminary experimental anticancer activity of cecropins. Pept. Res. 7, 265-269 (1994).

32 Jacob, L. \& Zasloff, M. Potential therapeutic application of magainins and other antimicrobial agents of animal origin. Ciba. Found. Symp. 186, 197-223 (1994).

33 Baker, M. A., Maloy, W. L., Zasloff, M. \& Jacob, L. S. Anticancer efficacy of magainin2 and analogue peptides. Cancer Res. 53, 3052-3057 (1993).

34 Marcos, J. F. \& Gandía, M. Antimicrobial Peptides: to membrane and beyond. Expert. Opin. Drug Discov. 4, 659-671 (2009).

35 Brogden, K. A. Antimicrobial peptides: pore formers or metabolic inhibitors in bacteria? Nat. Rev. Microbiol. 3, 238-250 (2005).

36 Gandhi, Rádis-Baptista et al. Membrane-translocating peptides and toxins: from nature to bedside. Sociedade Brasileira de Química 19, 211-225 (2008).

37 Marlow, V. L. et al. Essential role for the BacA protein in the uptake of a truncated eukaryotic peptide in Sinorhizobium meliloti. J. Bacteriol. 191, 1519-1527 (2009).

38 Mattiuzzo, M. et al. Role of the Escherichia coli SbmA in the antimicrobial activity of proline-rich peptides. Mol. Microbiol. 66, 151-163 (2007).

39 Ganz, T. Defensins: antimicrobial peptides of innate immunity. Nat. Rev. Immunol. 3, 710-720 (2003)

40 Hale, J. D. \& Hancock, R. E. Alternative mechanisms of action of cationic antimicrobial peptides on bacteria. Expert Rev. Anti. Infect. Ther. 5, 951-959 (2007).

41 Handler, A. A., Lim, J. E. \& Losick, R. Peptide inhibitor of cytokinesis during sporulation in Bacillus subtilis. Mol. Microbiol. 68, 588-599 (2008).

42 Hasper, H. E. et al. An alternative bactericidal mechanism of action for lantibiotic peptides that target lipid II. Science 313, 1636-1637 (2006).

43 Sass, V. et al. Human $\beta$-defensin 3 inhibits cell wall biosynthesis in Staphylococci. Infect. Immun. 78, 2793-2800 (2010).

44 Cashman, K. A. Bayer, A. S. \& Yeaman, M. R. Diversity in susceptibility to antibiotics and cationic peptides among Enterococcus faecalis or Enterococcus faecium isolates of diverse clinical or geographic origin, abstr. A-26. Abstr. 98th Gen. Meet. Am. Soc. Microbiol., Atlanta, GA. American Society for Microbiology, Washington, DC (1998).

45 Fields, P. I., Groisman, E. A. \& Heffron, F. A Salmonella locus that controls resistance to microbicidal proteins from phagocytic cells. Science 243, 1059-1062 (1989).

$46 \mathrm{Oh}, \mathrm{J}$. T. Cationic peptides antimicrobials induce selective transcription of micF and osmY in Escherichia coli. Biochim. Biophys. Acta. Biomembr. 1463, 43-54 (2000).

47 Yeaman, M. R. \& Yount, N. Y. Mechanisms of antimicrobial peptide action and resistance. Pharmacol. Rev. 55, 27-55 (2003).

48 Zahner, D. et al. Human antimicrobial peptide LL-37 induces MefE/Mel-mediated macrolide resistance in Streptococcus pneumoniae. Antimicrob. Agents. Chemother. 54, 3516-3519 (2010). 
49 Ganz, T. The role of antimicrobial peptides in innate immunity. Integr. Comp. Biol. 43, 300-304 (2003).

50 Niyonsaba, F. et al. Antimicrobial peptides human beta-defensins stimulate epidermal keratinocyte migration, proliferation and production of proinflammatory cytokines and chemokines. J. Invest. Dermatol. 127, 594-604 (2007).

51 Shai, Y. \& Oren, Z. From 'carpet' mechanism to de-novo designed diastereomeric cellselective antimicrobial peptides. Peptides 22, 1629-1641 (2001).

52 Lohner, K. \& Blondelle, S. E. Molecular mechanisms of membrane perturbation by antimicrobial peptides and the use of biophysical studies in the design of novel peptide antibiotics. Comb. Chem. High Throughput Screen 8, 241-256 (2005).

53 Gartia, A. André Gratia: a forerunner in microbial nad viral genetics. Genetics 156 471-476 (2000).

54 Drider, D., Fimland, G., Hechard, Y., McMullen, L. M. \& Prevost, H. The continuing story of class Ila bacteriocins. Microbiol. Mol. Biol. 70, 564-582 (2006).

55 Casaus, P. et al. Enterocin B, a new bacteriocin from Enterococcus faecium T136 which can act synergistically with enterocin A. Microbiology 143, 2287-2294 (1997).

56 Cintas, L. M., Casaus, P., Havarstein, L. S., Hernandez, P. E. \& Nes, I. F. Biochemical and genetic characterization of enterocin $\mathrm{P}$, a novel secdependent bacteriocin from Enterococcus faecium P13 with a broad antimicrobial spectrum. Appl. Environ. Microbiol. 63, 4321-4330 (1997).

57 Cintas, L. M. et al. Enterocins L50A and L50B, two novel bacteriocins from Enterococcus faecium L50 are related to Staphylococcal haemolysins. J. Bacteriol. 180, 1988-1994 (1998).

58 Cintas, L. M. et al. Biochemical and genetic evidence that Enterococcus faecium L50 produces enterocins $\angle 50 A$ and $\angle 50 B$, the sec-dependent enterocin $P$, and novel bacteriocin secreted without an $\mathrm{N}$-terminal extension termed enterocin $\mathrm{Q}$. J. Bacteriol. 182, 6806-6814 (2000).

59 Marekova, M. \& Lauková, A. Enterocin M-a New Bacteriocin Produced by Enterococcus faecium AL41 and its Potential Use. Proceedings of 'XX. Days of Animal Physiology' (Czech Republic, Slovak, Trest, 2002).

60 Nes, I. F. et al. Biosynthesis of bacteriocins in lactic acid bacteria. Anton. von. Leeuwenhook Int 70, 113-128 (1996).

61 Raaijmakers, J. M., de Bruijn, I. \& de Kock, M. J. Cyclic lipopeptide production by plant associated Pseudomonas spp.: diversity, activity, biosynthesis, and regulation. Mol. Plant Microbe Interact. 19, 699-710 (2006).

62 Shida, O., Takagi, H., Kadowaki, K. \& Komagata, K. Proposal for two new genera, Brevibacillus gen. nov. and Aneurinibacillus gen. nov. Int. J. Syst. Bacteriol. 46, 939-946 (1996).

63 Smirnova, T. A., Minenkova, I. B., Orlova, M. V., Lecadet, M. M. \& Azizbekyan, R. R. The crystal-forming strains of Bacillus laterosporus. Res. Microbiol. 147, 343-350 (1996)

64 Huang, X. et al. An extracellular protease from Brevibacillus laterosporus G4 without parasporal crystals can serve as a pathogenic factor in infection of nematodes. Res. Microbiol. 156, 719-727 (2005).

65 Desjardine, K. et al. Tauramamide, a lipopeptide antibiotic produced in culture by Brevibacillus laterosporus isolated from a marine habitat: structure elucidation and synthesis. J. Nat. Prod. 70, 1850-1853 (2007).

66 Krachkovskii, S. A. et al. Isolation, biological properties, and spatial structure of antibiotic loloatin A. Russ. J. Bioorg. Chem. 28, 269-273 (2002).

67 Zhao, J. et al. Purification and characterization of a novel antimicrobial peptide from Brevibacillus laterosporus strain A60. Peptides 33, 206-211 (2012).

68 Dubos, R. J. Studies on a bactericidal agent extracted from a Soil Bacillus: I. preparation of the agent. Its activity in VIT. J. Exp. Med. 70, 1-10 (1939).

69 Babasaki, K., Takao, T. Shimonishi, Y. \& Kurahashi, K. Subtilocin A, a new antibiotic peptide produced by Bacillus subtilis 168: isolation, structure analysis and biogenesis. J. Biochem. 98, 585-603 (1985).

70 Martin, N. I. et al. Structural characterization of lacticin 3147, a two peptide lantibiotic with synergistic activity. Biochemistry 43, 3049-3056 (2004).

$71 \mathrm{Hajji}, \mathrm{M}$. et al. A highly thermostable antimicrobial peptide from Aspergillus clavatus ES1: biochemical and molecular characterization. J. Ind. Microbiol. Biotechnol. 37, 805-813 (2010)

72 Augustin, R. et al. Activity of the novel peptide arminin against multiresistan human pathogens shows the considerable potential of phylogenetically ancient organisms as drug sources. Antimicrob. Agents Chemother 53, 5245-5250 (2009)

73 Bulet, P. \& Stocklin, R. Insect antimicrobial peptides: structures, properties and gene regulation. Protein Pept. Lett. 12, 3-11 (2005).

74 Samakovlis, C., Kimbrell, D. A., Kylsten, P., Engstrom, A. \& Hultmark, D. The immune response in Drosophila: pattern of cecropin expression and biological activity. EMBO J. 9, 2969-2976 (1990).

75 Fontana, R. et al. Jelleines: a family of antimicrobial peptides from the royal jelly of honeybees (Apis mellifera). Peptides 25, 919-928 (2004)

76 Cao, L. et al. StCT2, a new antibacterial peptide characterized from the venom of the scorpion Scorpiops tibetanus. Peptides 36, 213-220 (2012).

77 Wegener, K. L. et al. Host defence peptides from the skin glands of the Australian Blue Mountains tree-frog Litoria citropa-Solution structure of the antibacterial peptide citropin 1.1. Eur. J. Biochem. 265, 627-637 (1999).

78 Wang, Y. et al. Snake cathelicidin from Bungarus fasciatus is a potent peptide antibiotics. PLoS One 16, e3217 (2008).

79 Sachidananda, M. K., Murari, S. K. \& Channe Gowda, D. Characterization of an antibacterial peptide from Indian cobra (Naja naja) venom. J. Venom. Anim. Toxins incl. Trop. Dis. 13, 446-461 (2007).
80 Evans, E. W., Beach, G. G., Wunderlich, J. \& Harmon, B. G. Isolation of antimicrobia peptides from avian heterophils. J. Leukoc. Biol. 56, 661-665 (1994).

81 Shi, J. \& Ganz, T. The role of protegrins and other elastase-activated polypeptides in the bactericidal properties of porcine inflammatory fluids. Infect. Immun. 66, 3611-3617 (1998).

82 Tsai, H. \& Bobek, L. A. Human salivary histatins: promising anti-fungal therapeutic agents. Crit. Rev. Oral Biol. Med. 9, 480-497 (1998)

83 Edgerton, M. et al. Candidacidal activity of salivary histatins. Identification of a histatin 5-binding protein on Candida albicans. J. Biol. Chem. 273, 20438-20447 (1998).

84 Jones, B. L. \& Mak, A. S. Amino acid sequences of the two $\alpha$ - purothionins of hexaploid wheat. Cereal Chem. 54, 511-523 (1977).

85 Castro, M. S. \& Fontes, W. Plant defense and antimicrobial peptides. Protein Pept. Lett. 12, 11-16 (2005).

86 Marr, A. K., Gooderham, W. J. \& Hancock, R. E. Antibacterial peptides for therapeutic use: obstacles and realistic outlook. Curr. Opin. Pharmacol. 6, 468-472 (2006).

87 Lien, S. \& Lowman, H. B. Therapeutic peptides. Trends Biotechnol. 21, 7 (2003).

88 Calderon, L. A. \& Stabeli, R. G. in Changing Diversity in Changing Environment 211-242 (2011).

89 Castells, P. et al. Isolation and characterization of abaecin, a major antibacteria response peptide in the honeybees (Apis mellifera). Eur. J. Biochem. 187, 381-386 (1990).

$90 \mathrm{Wu}, \mathrm{L}$. P. et al. Characterization and amino acid sequencing of $\mathrm{y} 3$, an antiviral protein from mushroom Coprinus comatus. Chinese J. Biochem. Mol. Bio1. 24, 597-603 (2008).

91 Casteels-Jossons, K., Capaci, T., Casteels, P. \& Tepst, P. Apidaecin multipeptide precursor structure: a putative mechanism for amplification of the insect antibacterial response. EMBO J. 12, 1569-1578 (1993).

92 Rozek, T. et al. The antibiotic and anticancer active aurein peptides from Australian bell frogs Litoria aurea and Litoria raniformis the solution structure of aurein 1.2. Eur. J. Biochem. 267, 5330-5341 (2000)

93 Gennaro, R., Skerlavaj, B. \& Romeo, D. Purification, composition, and activity of two bactenecins, antibacterial peptides of bovine neutrophils. Infect. Immun. 57, 3142-3146 (1989)

94 Dickinson, L., Russell, V. \& Dunn, P. E. A family of bacteria-regulated, cecropin D-like peptides from Manduca sexta. J. Biol. Chem. 263, 19424-19429 (1988).

95 Morikawa, N., Hagiwara, N. \& Nakajima, T. Brevinin-1 and -2, unique antimicrobial peptide from the skin of the frog Rana brevipoda porsa.. Biochem. Biophys. Res. Commun. 189, 184-190 (1992).

96 Cho, J. H., Sung, B. H. \& Kim, S. C. Buforins: histone H2A-derived antimicrobial peptides from toad stomach. Biochim. Biophys. Acta 1788, 1564-1569 (2009)

97 Kim, H. S., Park, C. B., Kim, M. S. \& Kim, S. C. cDNA cloning and characterization of buforin I, an antimicrobial peptide: a cleavage product of histone H2A. Biochem. Biophys. Res. Commun. 229, 381-387 (1996).

98 Wong, H., Bowie, J. H. \& Carver, J. A. The solution structure and activity of caerin 1.1 , an antimicrobial peptide from the Australian green tree frog Litoria splendid. Eur. J. Biochem. 247, 545-557 (1997).

99 Briolat, J. \& Metz-Boutigue, M. H. New Antimicrobial activity for the catecholamine release-inhibitory peptide from chromogranin A. Cell Mol. Life Sci. 62, 377-385 (2005)

100 Oh, J., Cajal, Y., Dhurjati, P. S., Van Dyk, T. K. \& Jain, M. K. Cecropins induce the hyperosmotic stress response in Escherichia coli. Biochim. Biophys. Acta 1415 235-245 (1998).

101 Marri, L., Dallai, R. \& Marchini, D. The novel antibacterial peptide ceratotoxin A alters permeability of the inner and outer membrane of Escherichia coli K-12. Curr. Microbiol. 33, 40-43 (1996).

102 Lee, I. H. et al. Clavanins, alpha-helical antimicrobial peptides from tunicate hemocytes. FEBS Lett. 400, 158-162 (1997).

103 Biggs, J. S., Rosenfeld, Y., Shai, Y. \& Olivera, B. M. Conolysin-Mt: a conus peptide that disrupts cellular membranes. Biochemistry 46, 12586-12593 (2007).

104 Kuhn-Nentwig, L. et al. Cupiennin 1, a new family of highly basic antimicrobia peptides in the venom of the spider Cupiennius salei (Ctenidae). J. Bio1. Chem. 277, 11208-11216 (2002)

105 Mor, A. \& Nicolas, P. Isolation and structure of novel defensive peptides from frog skin. Eur. J. Biochem. 219, 145-154 (1994).

106 Sato, K. et al. Membrane permeabilization induced by discodermin A, a novel marine bioactive peptide. Toxicon 39, 259-264 (2001).

107 Bulet, P. et al. A novel inducible antibacterial peptide of drosophila carries an O-glycosylated substitution. J. Biol. Chem. 268, 14893-14897 (1993)

108 Nolde, S. B. et al. Disulfide-stabilized helical hairpin structure and activity of a nove antifungal peptide EcAMP1 from seeds of barnyard grass (Echinochloa crus-galli). J. Biol Chem. 286, 25145-25153 (2011).

109 Rogozhin, E. A., Ryazantsev, D. Y., Grishin, E. V., Egorov, T. A. \& Zavriev, S. K. Defense peptides from barnyard grass (Echinochloa crusgalli L.) seeds. Peptides $\mathbf{3 8}$ 33-40 (2012)

110 Silva, P. I. Jr., Daffre, S. \& Bulet, P. Isolation and characterization of gomesin, an 18 residue cystein-rich defense peptide from the spider Acanthoscurria gomesiana hemocytes with required similarities to horseshoe crab antimicrobial peptide of the tachyplesin family. J. Biol. Chem. 275, 33464-33470 (2000).

111 Tasiemski, A. et al. Hedistin: A novel antimicrobial peptide containing bromotryptophan constitutively expressed in the NK cells-like of the marine annelid, Nereis diversicolor. Dev. Comp. Immunol. 31, 749-762 (2007). 
112 Lamberty, M. et al. Solution structures of the antifungal heliomicin and a selected variant with both antibacterial and antifungal activities. Biochemistry 40, 11995-12003 (2001).

113 Yoe, S. M., Kang, C. S., Han, S. S. \& Bang, I. S. Characterization and cDNA cloning of hinnavin II, a cecropin family antibacterial peptide from the cabbage butterfly, Artogeia rapae. Comp. Biochem. Physiol. B Biochem. Mol. Biol. 144, 199-205 (2006).

114 Jung, S. et al. Hydramacin-1, structure and antibacterial activity of a protein from the basal metazoan Hydra. J. Biol. Chem. 284, 1896-1905 (2009).

115 Miyashita, M. et al. A novel amphipathic linear peptide with both insect toxicity and antimicrobial activity from the venom of the scorpion Isometrus maculates. Biosci. Biotechnol. Biochem. 74, 364-369 (2010).

116 Selsted, M. E. et al. Indolicidin, a novel bactericidal tridecapeptide amide from neutrophils. J. Biol. Chem. 267, 4292-4295 (1992).

117 Erbe, A., Kerth, A., Dathe, M. \& Blume, A. Interactions of KLA amphipathic model peptides with lipid monolayers. Chembiochem. 10, 2884-2892 (2009).

118 Hwang, P. M., Zhou., N., Shan, X., Arrowsmith, C. H. \& Vogel, H. J. Threedimensional solution structure of lactoferricin B an antimicrobial peptide derived from bovine lactoferrin. Biochemistry 37, 4288-4298 (1998).

119 Cho, J. H., Park, C. B., Yoon, Y. G. \& Kim, S. C. Lumbricin I, a novel proline-rich antimicrobial peptide from the earthworm: purification, cDNA cloning and molecular characterization. Biochim. Biophys. Acta 1408, 67-76 (1998).

120 Yan, L. \& Adams, M. E. Lycotoxins, antimicrobial peptides from venom of wolf spider Lycosa carolinensis. J. Biol. Chem. 273, 2059-2066 (1998).

121 Zasloff, M. Magainins, a class of antimicrobial peptides from Xenopus skin: isolation, characterization of two active forms, and partial cDNA sequence of a precursor. Proc. Natl Acad. Sci. USA 84, 5449-5453 (1987).

122 Lai, R. et al. Antimicrobial peptides from skin secretion of chinese red belly toad Bombina maxima. Peptides 23, 427-435 (2002).

123 Kreil, G. Structure of mellitin isolated from two species of honeybees. FEBS Lett. 33, 241-244 (1973)

124 Gao, B., Sherman, P., Luo, L., Bowie, J. \& Zhu, S. Structural and functional characterization of two genetically related meucin peptides highlights evolutionary divergence and convergence in antimicrobial peptides. FASEB J. 23, 1230-1245 (2009).

125 Balseiro, P. et al. Mytilus galloprovincialis myticin C: a chemotactic molecule with antiviral activity and immunoregulatory properties. PLOS One 6, e23140 (2011).

126 Dorosz, J. et al. Membrane interactions of novicidin, a novel antimicrobial peptide: phosphatidylglycerol promotes bilayer insertion. J. Phys. Chem. B 114, 11053-11060 (2010).

127 Fernandes, J. M., Saint, N., Kemp, G. D. \& Smith, V. J. Oncorhyncin III: a potent antimicrobial peptide derived from the non-histone chromosomal protein $\mathrm{H} 6$ of rainbow trout Oncorhynchus mykiss. Biochem. J. 373, 621-628 (2003).

128 Huanga, E. \& Yousef, A. E. Draft genome sequence of Paenibacillus polymyxa OSYDF, which coproduces a lantibiotic, paenibacillin, and polymyxin E1. J. Bacteriol. 194, 4739-4740 (2012).

129 Park, I. Y., Park, C. B., Kim, M. S. \& Kim, S. C. Parasin I, an antimicrobial peptide derived from histone H2A in the catfish Parasilurus asotus. FEBS Lett. 437, 258-262 (1998)
130 Lazarovici, P., Primor., N. \& Loew, L. M. Purification and pore-forming activity of two hydrophobic polypeptides from the secretion of the red sea moses sole (Pardachirus marmoratus). J. Biol. Chem. 261, 16704-16713 (1986).

131 Pan, W., Liu, X., Ge, F., Hang, J. \& Zheng, T. Perinerin, a novel antimicrobial peptide purified from the clamworm Perinereis aibuhitensis grube and its partial characterization. J. Biochem. 135, 297-304 (2004).

132 Silphaduang, U. \& Noga, E. J. Antimicrobials: peptide antibiotics in mast cells of fish. Nature 414, 268-269 (2001).

133 Orivel, J. et al. Ponericins, new antibacterial and insecticidal peptide from the venom of the ant Pachycondyla goeldii. J. Bio1 Chem. 276, 17823-17829 (2001).

134 Gudmundsson, G. H. et al. Structure of the gene for porcine peptide 111 antibiotic PR-39, a cathelin gene family member: comparative mapping of the locus for the human peptide antibiotic FALL-39. Proc. Natl Acad. Sci. USA 92, 7085-7089 (1995).

135 Ursic-Bedoya, R., Buchhop, J., Joy, J. B., Durvasula, R. \& Lowenberger, C. Prolixicin: a novel antimicrobial peptide isolated from Rhodnius prolixus with differential activity against bacteria and Trypanosoma cruzi. Insect Mol. Biol. 20, 775-786 (2011).

136 da Silva, A. Jr et al. Avian anticoccidial activity of a novel membrane-interactive peptide selected from phage display library. Mol. Biochem. Parasitol. 120, 53-60 (2002).

$137 \mathrm{Kragol}, \mathrm{G}$. et al. The antibacterial peptide pyrrhocoricin inhibits the ATPase actions of DnaK and prevents chaperone-assisted protein folding. Biochemistry 40, 3016-3026 (2001)

138 Clark, D. P., Durell, S., Maloy, W. L. \& Zasloff, M. Ranalexin. A novel antimicrobial peptide from bullfrog (Rana catesbeiana) skin, structurally related to the bacterial antibiotic, polymyxin. J. Biol. Chem. 269, 10849-10855 (1994).

139 Goraya, J. et al. Peptides with antimicrobial activity from four different families isolated from the skins of the north American frogs Rana luteiventris, Rana berlandieri and Rana pipiens. Eur. J. Biochem. 267, 894-900 (2000).

140 Hirakura, Y., Kobayashi, S. \& Matsuzaki, K. Specific interactions of the antimicrobial peptide cyclic beta-sheet tachyplesin I with lipopolysaccharides. Biochim. Biophys. Acta 1562, 32-36 (2002)

141 Dahiya, R. \& Gautam, H. Total synthesis and antimicrobial activity of a natural cycloheptapeptide of marine origin. Mar. Drugs 8, 2384-2394 (2010).

142 Shieh, T. C. et al. Synthesis and properties of tachyplesin I, a lipopolysaccharidebinding peptide, from Tachypleus tridentatus. FEBS Lett. 252, 121-124 (1989).

143 Simmaco, M. et al. Temporins, antimicrobial peptides from the European red frog Rana temporaria. Eur. J. Biochem. 242, 788-792 (1996).

144 Wegener, K. L. et al. Host defence peptides from the skin glands of the Australian Blue Mountains tree-frog Litoria citropa. Solution structure of the antibacterial peptide citropin 1.1. Eur. J. Biochem. 265, 627-637 (1999).

145 Chernysh, S. et al. Antiviral and antitumoral peptides from insects. Proc. Natl Acad. Sci. USA 99, 12628-12632 (2002).

146 Samakovlis, C., Kylsten, P., Kimbrell, D. A., Engstroem, A. \& Hultmark, D. The andropin gene and its product, a male-specific antibacterial peptide in Drosophila melanogaster. EMBO J. 10, 163-169 (1991).

147 Gran, L. On the effect of a polypeptide isolated from 'Kalata-Kalta' (Oldenlandia affinis DC) on the oestrogen dominated uterus. Acta Pharmacol. Toxicol. (COpenh) 33, 400-408 (1973). 